J. Perinat. Med. 16 (1988) 333

\section{An application of the Markov process for quantitative prediction of labor progress}

\author{
Akira Nagamatsu, Takashi Koyanagi, Kenzo Hirose, Hiromasa Nakahara, and Hitoo \\ Nakano
}

Department of Gynecology and Obstetrics, Faculty of Medicine, Kyushu University, Fukuoka, Japan

\section{Introduction}

In the mid-1950's, FrIEDMAN [3] proposed a partogram made up of a series of values of cervical dilatation over a given period of time; thereby the progress of labor could be assessed to be normal or dysfunctional.

Subsequently, in 1970, HENDRICKs [4] developed a quantitative method which described the percentile values of cervical dilatation with advance in labor, after the woman in labor was admitted to the hospital. These approaches are extremely useful for evaluating the progress of labor retrospectively but not for predicting the course of labor. When attempting to predict the course of labor, information about cervical dilatation in the individual must be quantitatively described in a sequential time arrangement.

Assuming that labor is a state- and time-related phenomenon during a period ranging from the onset of labor pain to the expelling of the baby: the initial and terminal points, respectively, the labor process can be considered as a mathematical model suitable for the application of the Markov process $[6,10]$.

Thus, from this point of view, we made a study of the progress of labor, with regard to whether or not the course of labor could be predicted.

\section{Material and methods}

Included in this study were 625 primiparas who went into spontaneous labor between 37 and 41 weeks of gestation with a single fetus of cephalic

\section{Curriculum vitae}

AkIRA Nagamatsu, M. D.,was born in 1954, in Fukuoka, Japan and graduated from Tottori University School of Medicine in 1982. He finished his postgraduate study in the Department of Gynecology and Obstetrics, Faculty of Medicine, Kyushu University, Fukuoka. His main interest is the application of

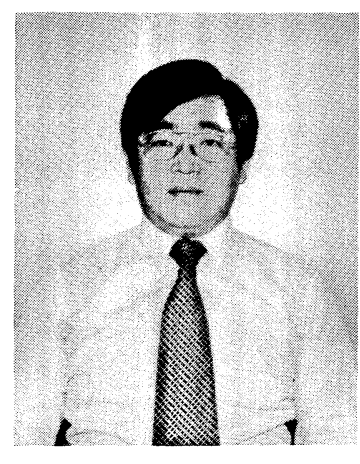
computers in the field of obstetric medicine.

presentation. The entire course of labor in these cases was recorded in detail on FRIEDMAN's partogram from before $4 \mathrm{~cm}$ cervical dilatation until delivery. When applying the Markov process, the sequence of labor progress was divided into eight categories: every $1 \mathrm{~cm}$ of cervical dilatation from $4 \mathrm{~cm}$ to $10 \mathrm{~cm}$ and delivery of the baby per 30 minute time unit. Using data obtained from all the cases, after converting information on the partogram per individual into such a form as applicable to the Markov process designed above, the transition matrix with 8 by 8 state-categories both in columns and rows was calculated, in which the value in each element was indicative of the percent of probability of progression in labor from one given state to another over a 30-minute period. These data were analyzed by micro-computer system (NEC 9801vm2), using BASIC computer language. 


\section{Results}

Table I shows the initial transition matrix (top) thus obtained, indicating any paired combination among the 8 by 8 categories. For example, the probability that a case will move from $4 \mathrm{~cm}$ at present to $5 \mathrm{~cm} 30$ minutes later is $21.8 \%$. The probability that it will move from $4 \mathrm{~cm}$ to $6 \mathrm{~cm}$ within 30 minutes is $7.8 \%$. This matrix was then multiplied by an identical one in order to produce the new transition matrix at 30 minute intervals. For instance, the matrices obtained after multiplying the initial matrix three and 14 times provides the transition matrices, respectively 90 minutes and 7 hours later, as shown in table I (middle and bottom). Thus, interpolating the values of transition probability between any two consecutive state-categories, a specially-devised graph was obtained (figure 1). In this graph, the relation between a given state and a given time is quantitatively described as a general rule of labor progress in the human, thereby available for predicting individual prognosis of labor. For example, a case who is at $4 \mathrm{~cm}$ cervical dilatation at present has a $95 \%$ confidence rate of reaching $5 \mathrm{~cm}$ and $7 \mathrm{~cm}$, at latest within 4 and 5 hours, respectively, as shown in figure 1.

Table I. Transition matrices with 8 by 8 statestructures.

\begin{tabular}{r|rrrrrrrr}
\hline & $4 \mathrm{~cm}$ & $5 \mathrm{~cm}$ & $6 \mathrm{~cm}$ & $7 \mathrm{~cm}$ & $8 \mathrm{~cm}$ & $9 \mathrm{~cm}$ & $10 \mathrm{~cm}$ & $\mathrm{D}$ \\
\hline $4 \mathrm{~cm}$ & 62.7 & 21.8 & 7.8 & 2.7 & 2.4 & 1.4 & 1.0 & 0.2 \\
$5 \mathrm{~cm}$ & 0.0 & 40.5 & 32.3 & 11.2 & 6.2 & 5.3 & 2.9 & 1.6 \\
$6 \mathrm{~cm}$ & 0.0 & 0.0 & 30.6 & 31.5 & 17.1 & 9.0 & 8.8 & 3.0 \\
$7 \mathrm{~cm}$ & 0.0 & 0.0 & 0.0 & 21.3 & 31.7 & 22.9 & 18.7 & 5.4 \\
$8 \mathrm{~cm}$ & 0.0 & 0.0 & 0.0 & 0.0 & 17.9 & 33.6 & 36.8 & 11.7 \\
$9 \mathrm{~cm}$ & 0.0 & 0.0 & 0.0 & 0.0 & 0.0 & 19.2 & 56.0 & 24.8 \\
$10 \mathrm{~cm}$ & 0.0 & 0.0 & 0.0 & 0.0 & 0.0 & 0.0 & 52.0 & 48.0 \\
$D \mathrm{~cm}$ & 0.0 & 0.0 & 0.0 & 0.0 & 0.0 & 0.0 & 0.0 & 100.8 \\
\hline
\end{tabular}

\begin{tabular}{r|rrrrrrrr}
\hline & $4 \mathrm{~cm}$ & $5 \mathrm{~cm}$ & $6 \mathrm{~cm}$ & $7 \mathrm{~cm}$ & $8 \mathrm{~cm}$ & $9 \mathrm{~cm}$ & $10 \mathrm{~cm}$ & $\mathrm{D}$ \\
\hline $4 \mathrm{~cm}$ & 24.7 & 17.7 & 14.7 & 9.6 & 8.1 & 7.4 & 10.6 & 7.3 \\
$5 \mathrm{~cm}$ & 0.0 & 6.6 & 12.3 & 12.7 & 12.7 & 13.2 & 23.1 & 19.5 \\
$6 \mathrm{~cm}$ & 0.0 & 0.0 & 2.9 & 6.4 & 10.1 & 14.1 & 33.1 & 33.5 \\
$7 \mathrm{~cm}$ & 0.0 & 0.0 & 0.0 & 1.0 & 3.7 & 9.0 & 36.4 & 49.9 \\
$8 \mathrm{~cm}$ & 0.0 & 0.0 & 0.0 & 0.0 & 0.6 & 3.5 & 31.3 & 64.6 \\
$9 \mathrm{~cm}$ & 0.0 & 0.0 & 0.0 & 0.0 & 0.0 & 0.7 & 22.8 & 76.5 \\
$10 \mathrm{~cm}$ & 0.0 & 0.0 & 0.0 & 0.0 & 0.0 & 0.0 & 14.1 & 85.9 \\
$\mathrm{Dcm}$ & 0.0 & 0.0 & 0.0 & 0.0 & 0.0 & 0.0 & 0.0 & 100.0 \\
\hline
\end{tabular}

\begin{tabular}{r|llllllll}
\hline & $4 \mathrm{~cm}$ & $5 \mathrm{~cm}$ & $6 \mathrm{~cm}$ & $7 \mathrm{~cm}$ & $8 \mathrm{~cm}$ & $9 \mathrm{~cm}$ & $10 \mathrm{~cm}$ & $\mathrm{D}$ \\
\hline $4 \mathrm{~cm}$ & 0.1 & 0.1 & 0.2 & 0.2 & 0.2 & 0.3 & 2.2 & 96.6 \\
$5 \mathrm{~cm}$ & 0.0 & 0.0 & 0.0 & 0.0 & 0.0 & 0.0 & 0.3 & 99.7 \\
$6 \mathrm{~cm}$ & 0.0 & 0.0 & 0.0 & 0.0 & 0.0 & 0.0 & 0.1 & 99.9 \\
$7 \mathrm{~cm}$ & 0.0 & 0.0 & 0.0 & 0.0 & 0.0 & 0.0 & 0.0 & 100.0 \\
$8 \mathrm{~cm}$ & 0.0 & 0.0 & 0.0 & 0.0 & 0.0 & 0.0 & 0.0 & 100.0 \\
$9 \mathrm{~cm}$ & 0.0 & 0.0 & 0.0 & 0.0 & 0.0 & 0.0 & 0.0 & 100.0 \\
$10 \mathrm{~cm}$ & 0.0 & 0.0 & 0.0 & 0.0 & 0.0 & 0.0 & 0.0 & 100.0 \\
$\mathrm{D} \mathrm{cm}$ & 0.0 & 0.0 & 0.0 & 0.0 & 0.0 & 0.0 & 0.0 & 100.0 \\
\hline
\end{tabular}

Table I. Initial transition matrix (top) with 8 by 8 state-structures, where the value in each element indicates the percent of probability from one given state in columns to another in rows as an utterance over a 30-minute period. Numerals and "D" show the states of cervical dilatation per one cm and delivery of the baby, respectively. The transition matrix 90-minutes later (middle) calculated by multiplying the initial matrix by itself three times. The translation matrix 7-hours later (bottom) calculated by multiplying the initial matrix by itself 14 times. 


\section{Discussion}

The labor process is a multifactorial phenomenon including unknown factors for making an analytical interpretation. In line with this, FRIEDMAN [3] first did successful work in terms of a partogram which is descriptive and feasible in clinical practice for a better comprehensive understanding of human labor progress; since, according to this method, a sequence of cervical dilatation is only required to be obtained on the elapsed time. Be-
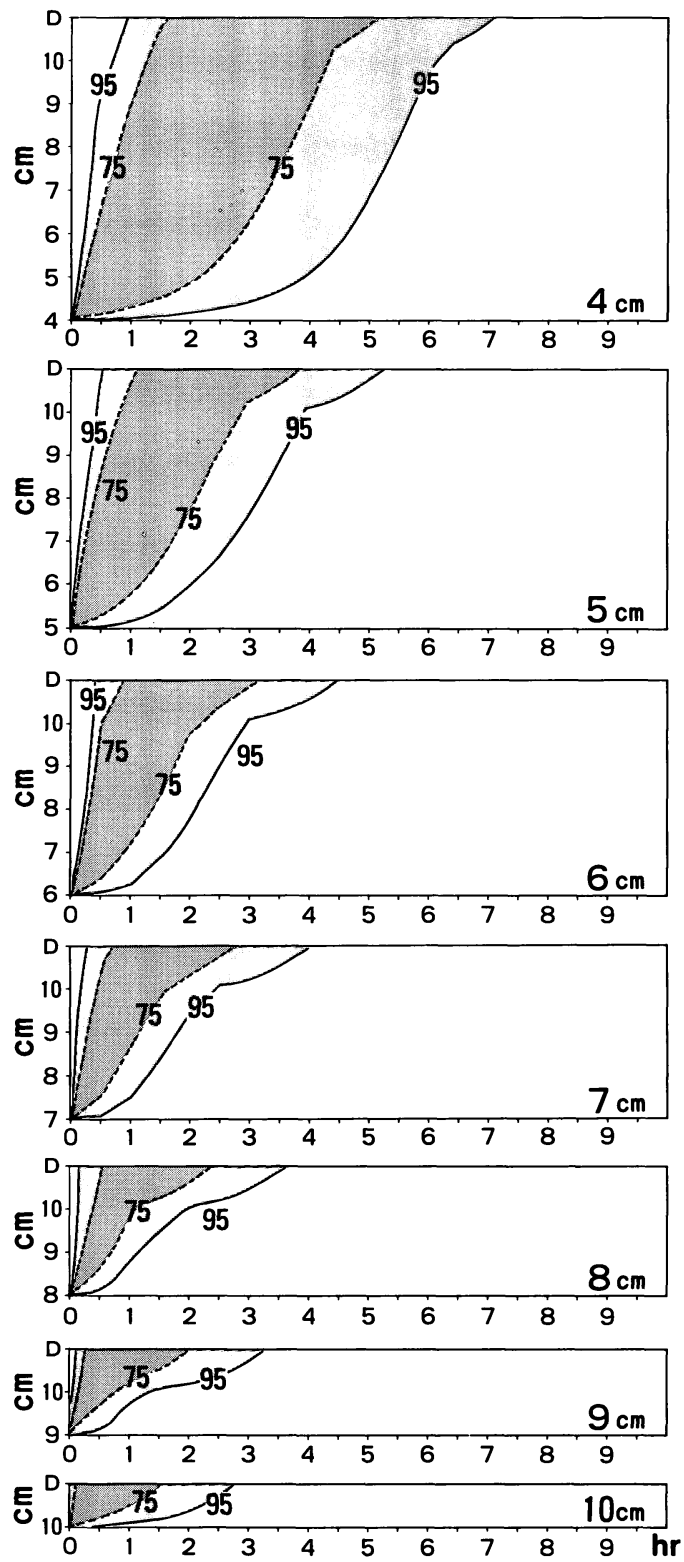

cause of an uncertain determination of the exact time of labor onset, there still remains the problem that neither normal nor dysfunctional courses of labor can be quantitatively evaluated. In contrast, HENDRICKS [4] set the starting point of observation at the time of the patient's admission to the hospital, thereby enabling us to describe the labor quantitatively. Thereafter, many authors $[2,8,9]$ studied these partograms extensively in relation to the underlying factors affecting the labor progress. There is little known with respect to prediction of labor progress $[1,5,7]$. This appears to be derived from the fact that neither FRIEDMAN's nor HENDRICKs's partograms can be expressed in such a way that information on one given state is connected to another. In other words, to make a predictive assessment of labor progress, it would be necessary to quantitatively link the state, e.g. magnitude of cervical dilatation, from the past through the present to the future.

For this purpose, we attempted to apply the Markov process to see if it would be useful in determining the actual labor progress. As stated by TracEY [10], the Markov process is based on the transition matrix with a probability structure. This matrix gives the probabilities by which one set of events or states, as presented here, is followed by another set of events. Thus, the transition matrix is a mathematical means of summarizing the sequence of events and also is a means of summarizing processes over time. Thus, using a transition matrix appropriately calculated, the Markov process comes to be a tool for predicting future states, according to the procedures of multiplication of the initial transition matrix by itself, to obtain values, for example, at 90 minutes and 7 hours. In this regard, the transition matrix obtained here was found to be of good predictive value for the actual course of labor, when attempting to check new cases (data not shown). These results when obtained under more definite conditions of random sampling will be further extended to quantitatively differentiate dysfunctional labor from the normal course of labor.

Figure 1. Prediction curves with confidence rates of 75 and 95 percents are shown at the different states of cervical dilatation of $4,5,6,7,8,9$ and $10 \mathrm{~cm}$, respectively from the top to the bottom. The vertical axis shows the magnitude of cervical dilatation (cm) and delivery of the baby, as abbreviated in the same fashion as in figure 1 , while the horizontal axis indicates time following a given state of cervical dilatation. 


\begin{abstract}
To quantitatively predict the progress of labor, we devised a mathematical model suitable for the Markov process. Included were 625 primiparas who went into spontaneous labor between 37 and 41 weeks of gestation with a cephalic presentation. When applying the Markov process, the sequence of labor was divided into eight categories from $4 \mathrm{~cm}$ cervical dilatation to delivery of the baby. Based on all data collected, a transition matrix

was calculated, using a microcomputer system, in which the value in each element showed the percent of probability of progression in labor from one given state to another over a 30-minute period. This matrix was found to be available for evaluating the course of labor in clinical practise with a good predictive value and therefore the Markov process could be confirmed to be actually applicable as an analytical model.
\end{abstract}

Keywords: Labor progress, Markov process, mathematical model, predictive assessment.

\title{
Zusammenfassung
} Anwendung des Markov Prozesses auf die quantitative
Vorhersage des Geburtsverlaufs

Um den Geburtsverlauf vorhersagen zu können, wurde ein mathematisches Modell auf der Basis eines Markov Prozesses verwendet. Die Studie umfaßte 625 Spontangeburten aus Schädellage von Erstgebärenden zwischen der 37. und 41. SSW. Zur Anwendung des Markov Prozesses wurde der Geburtsverlauf in 8 Abschnitte, von $4 \mathrm{~cm}$ Muttermundsöffnung bis hin zur Geburt des Babys, unterteilt. Mit Hilfe eines Mikrocomputers wurde eine Übergangsmatrix, die auf allen gesammelten Daten basierte, berechnet, wobei der Wert in jedem Matrixelement die prozentuale Wahrscheinlichkeit des Geburtsfortschritts von einem gegebenen Zustand zu einem anderen über einen Zeitraum von 30 Minuten beinhaltete. In der klinischen Praxis hat sich diese Matrix als geeignet zur Abschätzung des Geburtsverlaufs mit einem guten Vorhersagewert erwiesen und damit gleichzeitig den Markov Prozeß als ein geeignetes analytisches Modell bestätigt.

Schlüsselwörter: Geburtsverlauf, Markov Prozeß, mathematisches Modell, vorausschauende Einschätzung.

\section{Résumé}

Une application du procédé de Markov pour prévoir quantitativement l'évolution du travail

Nous avons élaboré un modèle mathématique adapté au procédé de Markov pour prévoir de façon quantitative l'évolution du travail. 625 primipares arrivées en travail spontanément entre 37 et 41 semaines avec une présentation céphalique ont été incluses. En utilisant le procédé de Markov on a divisé les phases de travail en huit catégories depuis une dilatation cervicale de $4 \mathrm{~cm}$ jusqu'à la naissance. A l'aide d'un systême microinformatique une matrice de transition fondée sur l'ensemble des données collectées, a été calculée; dans cette matrice de valeur de chaque élément montre le pourcentage de probabilité d'évolution du travail d'un état donné à un autre sur une période de 30 minutes. On a trouvé que cette matrice était utilisable pour évaluer le déroulement $\mathrm{du}$ travail en pratique clinique avec une bonne valeur prédictive et de plus on a pu confirmer que le procédé de Markov est actuellement applicable en tant que modèle analytique.

Mots-clés: Evolution du travail, modèle mathématique, prédiction, procédé de Markov.

Acknowledgements: We thank M. KURATA for technical assistance of computer analysis. This study was supported, in part, by the Ministry of Health and Welfare, Japan.

\section{References}

[1] CARDozo LD, DMF GibB, JWW StudD, RV VASANT, DJ COOPER: Predictive value of cervimetric labour patterns in primigravidae. Br J Obstet Gynecol 89 (1982) 33

[2] Duignan NM, JWW Studd, AO Hughes: Characteristics of normal labour in different racial groups. Br J Obstet Gynecol 82 (1975) 593
[3] Friedman EA: Graphic analysis of labor. Am J Obstet Gynceol 68 (1954) 1568

[4] Hendrucks CH, WE Brenner, G Kraus: Normal cervical dilatation pattern in late pregnancy and labor. Am J Obstet Gynecol 106 (1970) 1065 
[5] Karder N, M Cruddas, S Campbell: Estimating the probability of spontaneous delivery conditional on time spent in the second stage. $\mathrm{Br} \mathrm{J}$ Obstet Gynecol 93 (1986) 568

[6] KeNEMY JG, JL SNELL: Finite Markov chains. Van Nostrand Reinhold, New York 1960

[7] Melmed H, M Evans: Predictive value of cervical dilatation rates. I. Primipara labor. Obstet Gynecol 47 (1976) 511

[8] Philpott RH, WM Castle: Cervicographs in the management of labour in primigravidae. $\mathrm{Br} \mathrm{J} \mathrm{Ob-}$ stet Gynecol 79 (1972) 592
[9] Studd J, DR ClegG, RR SANDERS, AO Hughes: Identification of high risk labours by labour nomogram. Br Med J 7 (1975) 545

[10] TRACEY TJ: The $\mathrm{N}$ of 1 Markov chain design as a means of studying the stages of psychotherapy. Psychiatry 48 (1985) 196

Takashi Koyanagi, M.D.

Department of Gynecology and Obstetrics Faculty of Medicine

Kyushu University 60

Maidashi 3-1-1, Higashi-ku

Fukuoka 812

Japan 


\section{MaciBen · Stauber}

\section{Der andere Weg \\ zum eigenen Kind}

\section{Zeugung im Reagenzglas}

12 x $18 \mathrm{~cm}$. XII, 238 Seiten. Mit 21 Abbildungen und 2 Tabellen. 1988.

Kartoniert DM 34,- ISBN 3110101939

1978 wurde in England das erste sogenannte „Retortenbaby“ geboren; inzwischen gibt es weltweit mehrere tausend Kinder, die ihr Dasein der In-vitro-Fertilisation der Befruchtung außerhalb der Gebärmutter in einem Reagenzglas - verdanken. Der anfängliche Jubel über diesen Fortschritt der Medizin ist einer zunehmenden Unsicherheit und Skepsis gewichen, die angesichts von Leihmutterschaften und der Tiefkühlkonservierung befruchteter Eizellen verständlich ist. Fachübergreifende Arbeitsgruppen, die sich u. a: aus Medizinern, Juristen und Theologen zusammensetzen, haben sich damit beschäftigt, verbindliche Rahmenrichtlinien für die In-vitroFertilisation auszuarbeiten, die diese Unsicherheiten abbauen sollen.

Letzteres hat sich auch das vorliegende Buch als Ziel gesetzt: Es wendet sich vor allem an die Kinderwunschpaare, die in der In-vitro-Fertilisation ihre letzte Chance sehen. In ebenso sachgerechter wie allgemeinverständlicher Form werden die Befruchtungsvorgänge in vivo - in der Natur - sowie in vitro - im Reagenzglas dargestellt.

Interviews mit betroffenen Paaren geben Einblicke in die psychologische Auseinandersetzung mit dieser Behandlungsmethode. Die medizin-historische Einführung zeigt die Entwicklung der Sterilitätsbehandlung. Der Abschluß des Buches gibt einen Überblick über den gegenwärtigen Stand der medizinischen, juristischen und gesellschaftlichen Diskussion zum Thema „Retortenbaby“ und In-vitro-Fertilisation.
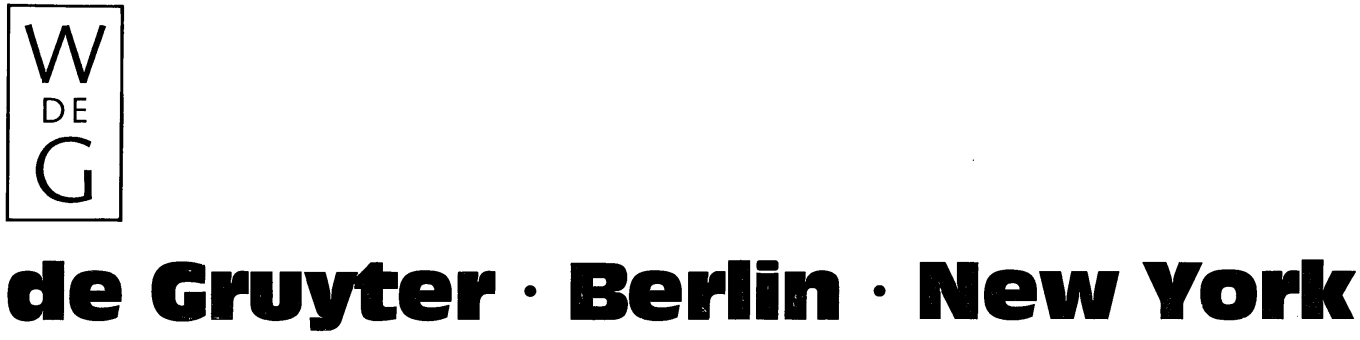